\title{
A MODEL TO OBTAIN A SERVPERF SCALE EVALUATION OF THE CRM CUSTOMER COMPLAINTS: AN APPLICATION TO THE 4G TELECOMMUNICATIONS SECTOR
}

\author{
Ramón Alberto CARRASCO ${ }^{1}$, María Francisca BLASCO ${ }^{1}$, \\ Jesús GARCÍA-MADARIAGA ${ }^{1}$, Ana PEDREÑO-SANTOS ${ }^{1}$, \\ Enrique HERRERA-VIEDMA ${ }^{2 *}$ \\ ${ }^{1}$ Department of Marketing and Market Research, Complutense University, \\ Campus de Somosaguas, Madrid 28223, Spain \\ ${ }^{2}$ Department of Computer Science and Artificial Intelligence, \\ University of Granada, Granada 18071, Spain
}

Received 23 March 2017; accepted 30 September 2017

\begin{abstract}
The relationship between customer churn and their complaints is sufficiently contrasted in the telecom sector. Therefore, a key part of a company's strategy is the measurement of this dissatisfaction. It is important to conduct periodic surveys on complaints in a standard form like the SERVPERF scale because it enables the organization to benchmark. Many of these complaints are stored in the company's CRM. Our first aim is to define a model to transform CRM customer complaints, expressed in natural language, into SERVPERF scales. In the proposed model, we use the 2-tuple model, which allows computing this linguistic data without losing information. Our second purpose is to implement a prototype to apply the model in a 4G Company. As a practical conclusion, most complaints in this emerging technology (which still has some deficiencies) are related to technical aspects of the services rather than to staff.
\end{abstract}

Keywords: SERVPERF, customer complaints, sentiment analysis, Fuzzy linguistic model, 2-tuple model, CRM trouble tickets.

JEL Classification: D81, M15, M31, L96, O32.

\section{Introduction}

Customer Relationship Management (CRM) is a combination of people, processes and technology with the aim of understanding the company's customers. It is an integrated approach to manage relationships, putting the focus on customer retention and relationship development (Jain, Tomar, \& Vishwakarma, 2016), and its capability is influenced both by customercentric management systems and social media technologies (Trainor, Andzulis, Rapp, \& Agnihotri, 2014). Its functionalities should be perfectly integrated with the Enterprise Resource

${ }^{\star}$ Corresponding author. E-mail: viedma@decsai.ugr.es

This is an Open Access article distributed under the terms of the Creative Commons Attribution License (http://creativecommons. org/licenses/by/4.0/), which permits unrestricted use, distribution, and reproduction in any medium, provided the original author and source are credited. 
Planning (ERP) software (Hadidi, Assaf, \& Alkhiami, 2017) for a successful implementation of the CRM. The relationship between customer churn (cancellations caused by switching to another company) and customers' complaints is sufficiently contrasted (Picón, Castro, \& Roldán, 2014; Hadden, Tiwari, Roy, \& Ruta, 2006). Many companies consider investments in complaint handling as means to increase customer commitment and to build customer loyalty (Yilmaz, Varnali, \& Kasnakoglu, 2016; Tax, Brown, \& Chandrashekaran, 1998). Successful complaint resolution can keep customer relations harmonious, making them even stronger. Through complaints, firms can learn about their own weaknesses as well as customers' needs (Maurer \& Schaich, 2011). Therefore, complaint management is an integral part of today's business strategies (Gambetta, Zorio-Grima, \& García-Benau, 2015).

Obviously, an important part of this strategy is the measurement of such customer satisfaction or, in other words, dissatisfaction. Service quality is essential to satisfy customers (F. A. Ferreira, J. J. Ferreira, Fernandes, Meiduté-Kavaliauskiené, \& Jalali, 2017; Chang \& Tsai, 2016; Naik, Gantasala, \& Prabhakar, 2010; Wisniewski, 2001). There are two broadly used research methodologies to assess quality service from the user perception perspective: SERVQUAL and SERVPERF. There is still no consensus, however, about which one is better (Jain \& Gupta, 2004). In both cases, they use customer questionnaires to obtain their conclusions. These questionnaires usually have about twenty-two items classified as five basic indicators: tangibility, reliability, responsiveness, assurance and empathy. Often, an n-point Likert scale is used to respond to the questions (Jain, 2013; Lai, Griffin, \& Babin, 2009), where customers express their agreement or disagreement with the corresponding item. The seminal SERVQUAL scale was first proposed by Parasuraman, Zeithaml, and Berry (1985). They obtain customers' responses to their expectations (E) and perceptions (P) and then define service quality as the gap between the customers' perceptions and the expectations, which is referred to as the P-E gap. The SERVPERF scale was developed by Cronin and Taylor (1994) and only uses customer perceptions $(\mathrm{P})$ as a measure of quality of service.

It is very important for a company to do regular surveys about customer complaints on a standard scale, either SERVQUAL or SERVPERF. The use of standard surveys enables the organization to benchmark both internally and externally, i.e., with other competing companies. This is especially interesting in stiff sectors where customers' churn rate is very high and therefore, retention policies are crucial. Among them is the $4 \mathrm{G}$ telecommunications sector, the subject matter of this paper. In this industry, we find examples of the use of both, SERVQUAL (Van der Wal, Pampallis, \& Bond, 2002) and SERVPERF (Shen, Tang, \& Zhu, 2010), to obtain customer satisfaction information. However, there are very few researches based on these standards that study only customer complaints. One of the main reasons is that customers who complain are frequently reluctant to answer questionnaires.

The support functions included in the CRM system (Piepiorra, 2015; Snyder, Steger, \& Landers, 2011) help to collect and sort customer requests, inquiries, disturbances, problems, etc. related to sold goods or services. Sales staff and management can obtain a quick overview of support activities related to customers. Therefore, the CRM stores these complaints expressed in natural language and from the customer's point of view. Some authors have proposed mechanisms such as ontologies to help understand the semantics of such complaints (Lee, Wang, \& Trappey, 2015). Often, these opinions contain disagreements with the service on one or more of the five indicators of which SERVQUAL and SERVPERF are composed. 
Therefore, it would be desirable to obtain SERVQUAL or SERVPERF surveys based on this unstructured information stored in the CRM, i.e., customer complaints expressed in natural language. This is the main purpose of this work. The first decision is the choice of the standard quality measurement model. We chose SERVPERF because customer complaints usually express their perceptions but rarely their expectations. These perceptions, which are not usually positive, are implicitly included in the customers' expectations.

This problem is related to the scope of Sentiment Analysis (SA), which is the broad field of study that analyses people's opinions, sentiments, evaluations, appraisals, attitudes, and emotions towards entities such as products, services, organizations, individuals, issues, events, topics, and their attributes (Nakov et al., 2013). Therefore, the task of SA is to obtain customers' sentiments by analysing large numbers of documents. In several SA approaches, as a result of this analysis, each document (i.e., the customer's opinion) is globally categorised into one of two categories: positive and negative, or on a linguistic $n$-point scale, e.g., very good, good, satisfactory, bad and very bad (Prabowo \& Thelwall, 2009). In our case, these SA approaches are not useful to achieve our primary goal because we have to qualify documents more roughly. For example, we have to identify the service features in these complaints that could be assigned to any SERVPERF scales, i.e., a characteristic that would be equivalent to an item of a SERVPERF questionnaire, and the sentiments that qualify these features, using linguistic $n$-point scales, which would be equivalent to the customer's response to the corresponding SERVPERF item. Therefore, within the same complaint, we could identify many different sentiments toward different features. Hence, the approach proposed by Hiroshi, Tetsuya, and Hideo (2004), which is based on the concept of sentiment unit, is more appropriate for our purposes.

These linguistic $n$-point scales that come from natural language, and therefore, have an important component of uncertainty, were successfully modelled using the fuzzy linguistic approach proposed by Zadeh (1975). Some later models, such as the 2-tuple model (Herrera \& Martínez, 2000), have allowed, under certain premises, computing these types of linguistic expressions without losing information and thus obtaining more accurate results in the context in which they were applied (Carrasco, Sánchez-Fernández, Muñoz-Leiva, Blasco, \& Herrera-Viedma, 2017; De Maio, Fenza, Loia, \& Orciuoli, 2016a; Cid-López, Hornos, Carrasco, \& Herrera-Viedma 2015; Li \& Liu, 2015; Mi, Shan, Qiang, Stephanie, \& Chen, 2014). For this reason, we use the 2-tuple model to represent and compute the sentiment identified.

After defining the model to transform the CRM textual customer complaints to the standard SERVPERF, the second purpose of this paper is to implement a prototype for practical application in the $4 \mathrm{G}$ telecom sector.

The rest of the article is structured as follows. Section 1 presents a review of the preliminary concepts used to explain the elements involved in the model, such as linguistic variables and 2-tuple representation, the SERVPERF scale, and its adaptations to $4 \mathrm{G}$ service perceptions, SA and the sentiment unit concept. Section 2 describes the model to obtain the SERVPERF scale evaluation from customer complaints. Section 3 displays a case study in which the presented model is applied to CRM information of Clearwire, a $4 \mathrm{G}$ Service Multinational Company located in Europe. Finally, the last section presents the conclusions and future research avenues. 


\section{Preliminaries}

In this section, we present the elementary foundations needed to understand our new model, the 2-tuple fuzzy linguistic approach, the SERVPERF scale and its adaptations to $4 \mathrm{G}$ service perceptions, SA and the sentiment units.

\subsection{Fuzzy linguistic modelling: the 2-tuple fuzzy linguistic approach}

The fuzzy linguistic approach (Zadeh, 1975) is a tool intended for modelling qualitative information in a problem. It is based on the concept of linguistic variables and has been satisfactorily used in many domains (Morente-Molinera, Mezei, Carlsson, \& Herrera-Viedma, 2017; Cid-López et al., 2015; Martínez-Cruz, Porcel, Bernabé-Moreno, \& Herrera-Viedma, 2015; Cabrerizo, Herrera-Viedma, \& Pedrycz, 2013).

We will analyse the approach to fuzzy linguistic modelling used in our system, i.e., the 2-tuple fuzzy linguistic approach (Herrera \& Martínez, 2000). This approach is a continuous model of information representation that has been used in many applications. The linguistic computational model based on linguistic 2-tuples carries out processes of "computing with words" without the loss of information that is typical of other classical and ordinal fuzzy linguistic approaches. To define it, we must establish the 2-tuple representation model and the 2-tuple computational model to represent and aggregate the linguistic information, respectively.

Let $S=\left\{s_{0}, \ldots, s_{T}\right\}$ be a linguistic term set with odd cardinality, where the mid-term represents an indifference value, and the rest of the terms are symmetric with respect to it. We assume that the semantics of labels is given by means of triangular membership functions and consider all terms distributed on a scale on which a total order is defined, i.e., $s_{i} \leq s_{j} \Leftrightarrow$ $i<j$. In this fuzzy linguistic context, if a symbolic method (Cabrerizo et al., 2013) aggregating linguistic information obtains a value of $b \in[0, T]$, and $b \notin\{0, \ldots, T\}$, then an approximation function is used to express the result in $S$.

Definition 1 (Herrera \& Martínez, 2000): Let $b$ be the result of an aggregation of the indexes of a set of labels assessed in a linguistic term set $S$, i.e., the result of a symbolic aggregation operation, $b \in[0, T]$. Let $i=$ round $(b)$ and $\alpha=b$-i be two values, such that $i \in[0, T]$ and $\alpha \in[-0.5$, $0.5)$, then $\alpha$ is called a Symbolic Translation.

The 2-tuple fuzzy linguistic approach is developed from the concept of symbolic translation by representing the linguistic information by means of 2-tuples $\left(s_{i}, \alpha_{i}\right), s_{i} \in S$ and $\alpha_{i}$ $\in[-0.5,0.5)$, where $s_{i}$ represents the information linguistic label, and $\alpha_{i}$ is a numerical value expressing the value of the translation from the original result $b$ to the closest index label, $i$, in the linguistic term set $\left(s_{i} \in S\right)$.

This model defines a set of transformation functions between numerical values and 2-tuples.

Definition 2 (Herrera \& Martínez, 2000): Let $S=\left\{s_{1}, \ldots, s_{T}\right\}$ be a linguistic term set and $b \in$ $[0, T]$ a value representing the result of a symbolic aggregation operation, then the 2-tuple that expresses the equivalent information to $b$ is obtained with the following function:

$$
\Delta:[0, T] \rightarrow S \times[-0.5,0.5)
$$




$$
\Delta(b)=\left(s_{i}, \alpha\right), \text { with }\left\{\begin{array}{l}
s_{i}, i=\operatorname{round}(b) \\
\alpha=b-i, \alpha \in[-0.5,0.5),
\end{array}\right.
$$

where round $(\cdot)$ is the usual round operation, $s_{i}$ has the closest index label to " $b$ ", and " $\alpha$ " is the value of the symbolic translation.

For all $\Delta$, there exists $\Delta^{-1}$, defined as:

$$
\Delta^{-1}\left(s_{i}, \alpha\right)=i+\alpha
$$

Moreover, it is obvious that the conversion of a linguistic term into a linguistic 2-tuple consists of adding a symbolic translation value of 0 , i.e., $s_{i} \in S \Rightarrow\left(s_{i}, 0\right)$.

The computational model is defined by presenting the following operators:

- Negation operator: $n e g\left(\left(s_{i}, \alpha\right)\right)=\Delta\left(T-\left(\Delta^{-1}\left(s_{i}, \alpha\right)\right)\right)$.

- Comparison of 2-tuples $\left(s_{k}, \alpha_{1}\right)$ and $\left(s_{l}, \alpha_{2}\right)$ :

- If $k<l$, then $\left(s_{k}, \alpha_{1}\right)$ is smaller than $\left(s_{l}, \alpha_{2}\right)$.

- If $k=l$, then

- If $\alpha_{1}=\alpha_{2}$, then $\left(s_{k}, \alpha_{1}\right)$ and $\left(s_{l}, \alpha_{2}\right)$ represent the same information;

- If $\alpha_{1}<\alpha_{2}$, then $\left(s_{k}, \alpha_{1}\right)$ is smaller than $\left(s_{l}, \alpha_{2}\right)$;

- If $\alpha_{1}>\alpha_{2}$, then $\left(s_{k}, \alpha_{1}\right)$ is larger than $\left(s_{l}, \alpha_{2}\right)$.

- Maximization operator: $\max \left(\left(s_{k}, \alpha_{1}\right),\left(s_{l}, \alpha_{2}\right)\right)=\left(s_{k}, \alpha_{1}\right)$, if $\left(s_{k}, \alpha_{1}\right)$ is larger than or equal to $\left(s_{l}, \alpha_{2}\right)$.

- Minimization operator: $\min \left(\left(s_{k}, \alpha_{1}\right),\left(s_{l}, \alpha_{2}\right)\right)=\left(s_{k}, \alpha_{1}\right)$, if $\left(s_{k}, \alpha_{1}\right)$ is smaller than or equal to $\left(s_{l}, \alpha_{2}\right)$.

- Aggregation operators. Information aggregation consists of obtaining a value that summarizes a set of values. Hence, the result of the aggregation of a set of 2-tuples must be a 2-tuple. Many aggregation operators can be found in the literature, which allow combining the information according to different criteria. Using the functions $\Delta$ and $\Delta^{-1}$ that transform numerical values into linguistic 2 -tuples and vice versa without loss of information, any of the existing aggregation operators can be easily extended to deal with linguistic 2-tuples. Below, we describe the aggregation operator used in our model.

- Arithmetic mean. The arithmetic mean is a classical numerical aggregation operator. Its equivalent operator for linguistic 2-tuples is defined as:

Definition 3 (Carrasco et al., 2017): Let $A=\left\{\left(l_{1}, \alpha_{1}\right), \ldots,\left(l_{n}, \alpha_{n}\right)\right\}$ be a set of linguistic 2-tuples, the 2-tuple arithmetic mean $\bar{A}^{e}$ is computed as:

$$
\bar{A}^{e}\left[\left(l_{1}, \alpha_{1}\right), \ldots,\left(l_{n}, \alpha_{n}\right)\right]=\Delta\left(\sum_{i=1}^{n} \frac{1}{n} \Delta^{-1}\left(l_{i}, \alpha_{i}\right)\right)=\Delta\left(\frac{1}{n} \sum_{i=1}^{n} \beta i\right) .
$$

\subsection{The SERVPERF scale}

As aforementioned, the SERVPERF scale was developed by Cronin and Taylor (1994) and uses customer perceptions as a measure of service quality. In this section, we explain the five dimensions proposed for the SERVPERF instrument and their adaptations to $3 \mathrm{G}$ service perceptions (Shen et al., 2010) which may be applied for the most part to $4 \mathrm{G}$ technologies:

- Tangibles: the appearance of physical facilities or equipment. The major advantage of $4 \mathrm{G}$ technology lies in high-speed data transmission. This feature of $4 \mathrm{G}$ technology 
can be perceived by practical experience through cell phone, wireless network modem and notebook using several services such as video call, online HD movie appreciation, network up/downstream file transmission, etc.

- Reliability: the ability to perform the promised service dependably and accurately, i.e., the reliability of operations. In a $4 \mathrm{G}$ context, it is important to build a quality network and supply customers with stable and fast digital transmission rate. 4G technology greatly enriches the service types and enhances the requirement to service level accordingly. Therefore, improving the level of operation and maintenance and doing one's best to fulfil the promise of the product to the customer is the major expression of reliability. Customers perceive this dimension through aspects such as network signal stability and coverage, ease of configuration of the network or devices, etc.

- Responsiveness: willingness to help customers and provide prompt service, i.e., customer care attention. A customer hotline timely responding to customers' inquiries and complaints about $4 \mathrm{G}$ businesses is the key to improve service quality. Customers perceive "responsiveness" as the proper resolution of their complaints and requests.

- Assurance: the level of protection of confidential information, the security of the operations and their ability to inspire trust and confidence. Considering that most customers lack information about $4 \mathrm{G}$ services, it is very important to build the trust relationship between telecom operators and customers technically and through marketing staff. Abundant professional knowledge of marketing staff and the practical operation level can make the customer feel the advantage of $4 \mathrm{G}$ service. Assurance on $4 \mathrm{G}$ technology can be perceived through absence of network outages, dropped calls, etc.

- Empathy: the level of attention (and its usefulness and suitability) to the needs of the uses of the system. Every customer hopes to feel that telecom operators understand and think highly of him. 4G technology enriches the service types of telecom operators. It is completely possible to provide customers, especially business customers, with the appropriate product and service for their characteristics by formulating comprehensive communication solutions to meet their personalized requirements. Customers perceive this dimension through the appropriate information provided, satisfactory treatment received by staff, etc.

Thus, we can define a SERVPERF questionnaire, $S P$, as $S P=\left\{S P_{1}, \ldots, S P_{n}\right\}, n=5$, where $S P_{1}=$ Tangibles, $S P_{2}=$ Reliability, $S P_{3}=$ Responsiveness, $S P_{4}=$ Assurance, and $S P_{5}=$ Empathy. That is, an $S P$ questionnaire consists of 5 sub-questionnaires $S P_{i}, i=1, \ldots, n$, one for each SERVPERF dimension. Each $S P_{i}$ has its own question definitions or items, i.e., $S P_{i}=$ $\left\{q_{1}{ }^{i}, \ldots, q_{\# S P i}{ }^{i}\right\}$, where $\# S P_{i}$ represents the number of items of $S P_{i}$. The total number of items is typically 22 (see Figure 1).

Assuming that we have several groups of users, $Y=\left\{y_{1}, \ldots, y_{m}\right\}$, which have filled in the form answering the corresponding items on questionnaire $S P$, we consider that $y_{k}\left(q_{j}^{i}\right), \forall k \in$ $\{1, \ldots, m\}, \forall i \in\{1, \ldots, n\}, \forall j \in\left\{1, \ldots, \# S P_{i}\right\}$ is the subjective opinion provided by the user $y_{k}$ on the item $q_{j}^{i}$, i.e., the user's assessment or perception of the feature contained in this item. Often, these assessments are expressed on $n$-point Likert scales (Jain, 2013; Lai et al., 2009) where customers express their agreement or disagreement with the corresponding item.

Taking into account the comments of this section, we suggest the specific 4G SERVPERF questionnaire included as Table 1. 


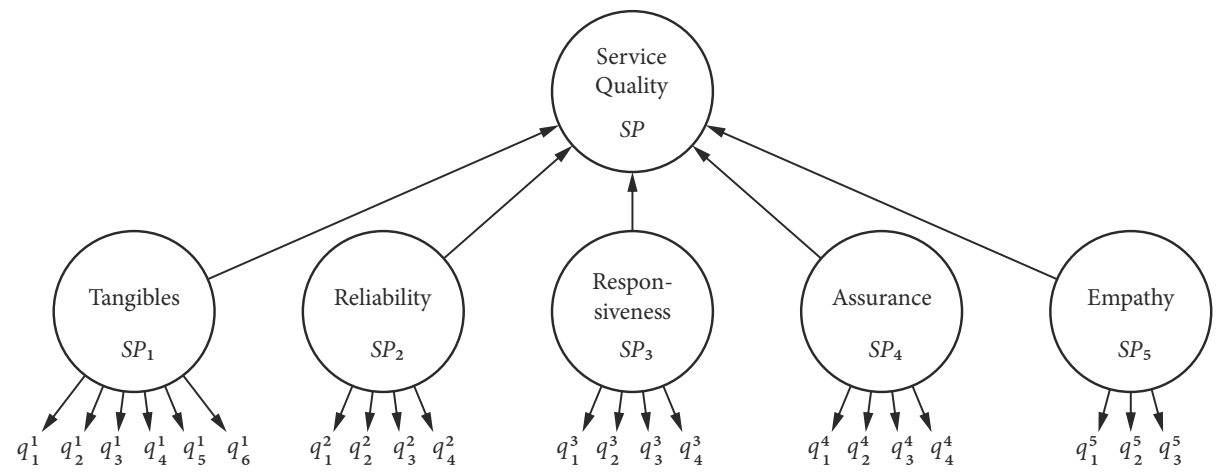

Figure 1. SERVPERF questionnaire (based on Cronin \& Taylor, 1994)

Table 1. 4G SERVPERF questionnaire

\begin{tabular}{|l|l|l|c|c|c|c|c|}
\hline$q_{j}^{i}$ & \multicolumn{1}{|c|}{ Question } & \multicolumn{1}{|c|}{$\begin{array}{c}\text { SERVPERF } \\
\text { Scale }\end{array}$} & $\begin{array}{c}\text { Strongly } \\
\text { disagree }\end{array}$ & $\begin{array}{c}\text { Dis- } \\
\text { agree }\end{array}$ & $\begin{array}{c}\text { Neither agree } \\
\text { nor disagree }\end{array}$ & Agree & $\begin{array}{c}\text { Strongly } \\
\text { agree }\end{array}$ \\
\hline$q_{1}{ }^{1}$ & $\begin{array}{l}\text { I can download files } \\
\text { correctly }\end{array}$ & Tangibles & 1 & 2 & 3 & 4 & 5 \\
\hline$q_{2}{ }^{1}$ & I can upload files correctly & Tangibles & 1 & 2 & 3 & 4 & 5 \\
\hline$q_{3}{ }^{1}$ & $\begin{array}{l}\text { I have a good experience } \\
\text { browsing the Internet }\end{array}$ & Tangibles & 1 & 2 & 3 & 4 & 5 \\
\hline$q_{4}{ }^{1}$ & $\begin{array}{l}\text { I can watch videos and } \\
\text { listen to music on line }\end{array}$ & Tangibles & 1 & 2 & 3 & 4 & 5 \\
\hline$q_{5}{ }^{1}$ & The connection is stable & Tangibles & 1 & 2 & 3 & 4 & 5 \\
\hline$q_{6}{ }^{1}$ & $\begin{array}{l}\text { I have a good speed } \\
\text { experience }\end{array}$ & Tangibles & 1 & 2 & 3 & 4 & 5 \\
\hline$q_{1}^{2}$ & $\begin{array}{l}\text { I can use the service } \\
\text { where I expected to }\end{array}$ & Reliability & 1 & 2 & 3 & 4 & 5 \\
\hline$q_{2}^{2}$ & $\begin{array}{l}\text { The service signal is } \\
\text { always on }\end{array}$ & Reliability & 1 & 2 & 3 & 4 & 5 \\
\hline$q_{3}^{2}$ & $\begin{array}{l}\text { The service configuration } \\
\text { is simple and easy }\end{array}$ & Reliability & 1 & 2 & 3 & 4 & 5 \\
\hline$q_{4}^{2}$ & $\begin{array}{l}\text { When needed, I have } \\
\text { made technical updates } \\
\text { easily }\end{array}$ & Reliability & 1 & 2 & 3 & 4 & 5 \\
\hline$q_{1}^{3}$ & $\begin{array}{l}\text { Employees give me } \\
\text { prompt solutions when I } \\
\text { have a problem }\end{array}$ & Responsiveness & 1 & 2 & 3 & 4 & 5 \\
\hline$q_{2}^{3}$ & $\begin{array}{l}\text { Employees always respond } \\
\text { to my requests }\end{array}$ & Responsiveness & 1 & 2 & 3 & 4 & 5 \\
\hline$q_{3}^{3}$ & $\begin{array}{l}\text { Employees take actions } \\
\text { when I make a complaint }\end{array}$ & Responsiveness & 1 & 2 & 3 & 4 & 5 \\
\hline$q_{4}^{3}$ & $\begin{array}{l}\text { Employees are } \\
\text { knowledgeable about the } \\
\text { products and issues }\end{array}$ & Responsiveness & 1 & 2 & 3 & 4 & 5 \\
\hline
\end{tabular}


End of Table 1

\begin{tabular}{|l|l|l|c|c|c|c|c|}
\hline$q_{j}^{i}$ & \multicolumn{1}{|c|}{ Question } & \multicolumn{1}{|c|}{$\begin{array}{c}\text { SERVPERF } \\
\text { Scale }\end{array}$} & $\begin{array}{c}\text { Strongly } \\
\text { disagree }\end{array}$ & $\begin{array}{c}\text { Dis- } \\
\text { agree }\end{array}$ & $\begin{array}{c}\text { Neither agree } \\
\text { nor disagree }\end{array}$ & Agree & $\begin{array}{c}\text { Strongly } \\
\text { agree }\end{array}$ \\
\hline$q_{1}^{4}$ & $\begin{array}{l}\text { I use the service with no } \\
\text { breakdowns }\end{array}$ & Assurance & 1 & 2 & 3 & 4 & 5 \\
\hline$q_{2}{ }^{4}$ & $\begin{array}{l}\text { I make and receive phone } \\
\text { calls correctly }\end{array}$ & Assurance & 1 & 2 & 3 & 4 & 5 \\
\hline$q_{3}^{4}$ & Downloads rarely fail & Assurance & 1 & 2 & 3 & 4 & 5 \\
\hline$q_{4}^{4}$ & Uploads rarely fail & Assurance & 1 & 2 & 3 & 4 & 5 \\
\hline$q_{1}{ }^{5}$ & $\begin{array}{l}\text { Employees give me } \\
\text { required information } \\
\text { properly }\end{array}$ & Empathy & 1 & 2 & 3 & 4 & 5 \\
\hline$q_{2}{ }^{5}$ & $\begin{array}{l}\text { When I have a problem } \\
\text { with any services, } \\
\text { employees show interest } \\
\text { in solving it }\end{array}$ & Empathy & 1 & 2 & 3 & 4 & 5 \\
\hline$q_{3}{ }^{5}$ & $\begin{array}{l}\text { Employees are very helpful } \\
\text { and their behaviour instils } \\
\text { confidence }\end{array}$ & Empathy & 1 & 2 & 3 & 4 & 5 \\
\hline
\end{tabular}

\subsection{Sentiment analysis and sentiment unit}

In the past, most researchers focused on assigning sentiments categorised into two categories (positive and negative) to documents. Other authors have proposed analyse sentiment at a fine-grained level, i.e. finding the sentiments of words, subjective expressions, subjective sentences and other sentiment units, to improve the effectiveness of a sentiment classification. In addition, the representation of these sentiments has been proposed through $n$-point scale, e.g., very good, good, satisfactory, bad and very bad (Prabowo \& Thelwall, 2009). In Table 2 we show several proposed models of special interest for the problem to be solved in this work.

As will be seen below, in our model, we need not only to obtain the assessment of the sentiment but also to understand the natural language semantically. For this purpose, we explain the SA approach that we use in our model:

- Hiroshi et al. (2004) define SA as a task to obtain customers' feelings as expressed in positive or negative comments, questions and requests, by analysing large numbers of documents expressed in natural language. They describe a method to extract a set of sentiment units from sentences, which is the key component of SA. They define these units as a sentiment, a predicate, one or more arguments of the predicate and a surface form. The sentiment polarises a sentiment unit into favourable and unfavourable. A predicate is a word, typically a verb or an adjective, that conveys the main notion of the sentiment unit. An argument is also a word, typically a noun that roughly corresponds to a subject and an object of the predicate in English. The surface form is the corresponding part in the original text that makes the notation of each sentiment unit more understandable for humans. Backus Normal Form (BNF) is often used to describe the syntax of languages, so the authors have used this technique to describe the syntax of the sentiment unit. Representation of the model as a set of the produc- 
1614 R. A. Carrasco et al. A model to obtain a SERVPERF scale evaluation of the CRM customer complaints ...

tion rules defined in BNF, in which the square brackets enclose optional elements, the symbols + and ${ }^{\star}$ indicate the possible repetition of the elements that follow ${ }^{\star} 0$ or more times and +1 or more times), and the symbol $\mid$ indicates alternative elements. Formally it is expressed as in Figure 2.

Table 2. State of the art of SA

\begin{tabular}{|c|c|c|c|c|}
\hline Application Areas & Objectives & Polarities & Models & References \\
\hline Camera reviews & qualify sentiment units & $\begin{array}{l}\text { positive, } \\
\text { negative }\end{array}$ & $\begin{array}{l}\text { Natural Language } \\
\text { Processing (NLP), } \\
\text { Pattern-Based }\end{array}$ & $\begin{array}{l}\text { Hiroshi et al. } \\
(2004)\end{array}$ \\
\hline $\begin{array}{l}\text { Document } \\
\text { Understanding } \\
\text { Conference (DUC) } \\
\text { Corpus (http://duc. } \\
\text { nist.gov/) }\end{array}$ & $\begin{array}{l}\text { qualify expression } \\
\text { sentiments }\end{array}$ & $\begin{array}{l}\text { positive, } \\
\text { negative }\end{array}$ & Probabilistic-Based & $\begin{array}{l}\text { Kim and } \\
\text { Hovy } \\
(2004)\end{array}$ \\
\hline Movie reviews & $\begin{array}{l}\text { qualify document } \\
\text { sentiments }\end{array}$ & $\begin{array}{l}n \text {-point } \\
\text { scale }\end{array}$ & $\begin{array}{l}\text { Support Vector } \\
\text { Machines, Logistic } \\
\text { Regression, } \\
\text { Metric Labeling }\end{array}$ & $\begin{array}{l}\text { Pang and Lee } \\
(2005)\end{array}$ \\
\hline $\begin{array}{l}\text { Multi-perspective } \\
\text { Question } \\
\text { Answering Opinion } \\
\text { (MPQA) Corpus }\end{array}$ & $\begin{array}{l}\text { quality phrase-level } \\
\text { sentiments }\end{array}$ & $\begin{array}{l}\text { positive, } \\
\text { negative }\end{array}$ & $\begin{array}{l}\text { Recognizing } \\
\text { Contextual Polarity }\end{array}$ & $\begin{array}{l}\text { Jain and } \\
\text { Nemade } \\
(2010)\end{array}$ \\
\hline $\begin{array}{l}\text { Tourism tour } \\
\text { reviews }\end{array}$ & $\begin{array}{l}\text { qualify document } \\
\text { sentiments }\end{array}$ & $\begin{array}{l}n \text {-point } \\
\text { scale with } \\
\text { grey 2-tuples } \\
\text { representation }\end{array}$ & $\begin{array}{l}\text { Calculate Greyness } \\
\text { Manually by Experts }\end{array}$ & $\begin{array}{l}\text { Mi et al. } \\
(2014)\end{array}$ \\
\hline $\begin{array}{l}\text { Financial } \\
\text { performance, } \\
\text { financial distress, } \\
\text { bankruptcy } \\
\text { forecasting }\end{array}$ & $\begin{array}{l}\text { qualify document } \\
\text { sentiments }\end{array}$ & $\begin{array}{l}n \text {-point } \\
\text { scale }\end{array}$ & $\begin{array}{l}\text { Logistic Regression, } \\
\text { Neural Networks, } \\
\text { Support Vector } \\
\text { Machines, Decision } \\
\text { Trees }\end{array}$ & $\begin{array}{l}\text { Hajek, Olej, } \\
\text { and Myskova } \\
(2014)\end{array}$ \\
\hline $\begin{array}{l}\text { Customer } \\
\text { satisfaction and } \\
\text { loyalty }\end{array}$ & $\begin{array}{l}\text { quantify and qualify } \\
\text { correlations among } \\
\text { statistical factors, and } \\
\text { extract } \\
\text { fuzzy rules }\end{array}$ & $\begin{array}{l}n \text {-point } \\
\text { scale with } \\
\text { fuzzy } \\
\text { representation }\end{array}$ & $\begin{array}{l}\text { Fuzzy-Based } \\
\text { Decision Support } \\
\text { System }\end{array}$ & $\begin{array}{l}\text { De Maio et al. } \\
\text { (2016b) }\end{array}$ \\
\hline
\end{tabular}

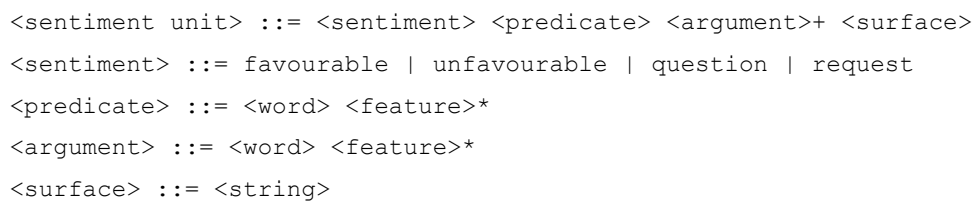

Figure 2. Definition of the sentiment unit (Hiroshi et al., 2004) 
Example 1 (Hiroshi et al., 2004). We have obtained these sentences from a customer's review of a digital camera:

It has an excellent lens but the price is too high. I don't think the quality of the recharger will give problems.

This review contained three sentiment units with the assessments expressed using brackets:

- [favourable] excellent (lens)

- [unfavourable] high (price)

- [favourable] problematic ${ }^{+ \text {neg }}$ (recharger)

\section{A model to obtain a 2-tuple SERVPERF scale evaluation of customer complaints}

The 4G SERVPERF questionnaire (Table 1) has been defined in Section 1.2. Now, the basic idea is to obtain the answers to the questionnaire about the complaints that are included in the CRM. Therefore, in our problem, we are dealing with unstructured information as the input of our system, i.e., the customer's complaints expressed in natural language. However, the output of our system is structured information, i.e., the assessment of each SERVPERF dimension, and it must be referred to an ordinal scale. As seen in Section 1.2, SERVPERF is commonly assessed using a $n$-Likert scale. Therefore, we will also use a Likert scale for the results of our system.

A Likert scale is a set of items, made up of approximately an equal number of favourable and unfavourable statements concerning the attitude object. People are asked to respond to each statement in terms of their own degree of agreement or disagreement. For example, on a 5-point Likert scale, they would be instructed to select one of the responses: "strongly agree", "agree", "neither agree nor disagree", "disagree”, or "strongly disagree" (see Table 1). Of course, these perceptions are characterized by uncertainty and fuzziness. Some authors consider that the use of conventional (crisp) numbers is not suitable to model these human perceptions and they consider that a better approach would be based on the use of linguistic assessments (Carrasco et al., 2017; Cid-López et al., 2015).

Therefore, we model such a Likert scale through the set $T=\left\{s_{0}, \ldots, s_{t}\right\}$, with the same characteristics of the set $S$ defined in section 1.1, i.e., $t$ is an odd number, the mid-term represents an indifference value, the rest of the terms are symmetric with respect to it, and the semantics of labels is given by means of triangular membership. In the Figure 3 we show an example of definition of a 5 -Likert scale.

Once this basic domain $T$ is defined, we can describe the process to obtain the SERVPERF scale value from the customer's complaints expressed in natural language. In this process, we will use the 2-tuple model (Section 1.1). This model will allow us to compute the results more precisely without losing the linguistic interpretability of the Likert scale used. As shown in Figure 4, our model contains several stages which we explain below. 


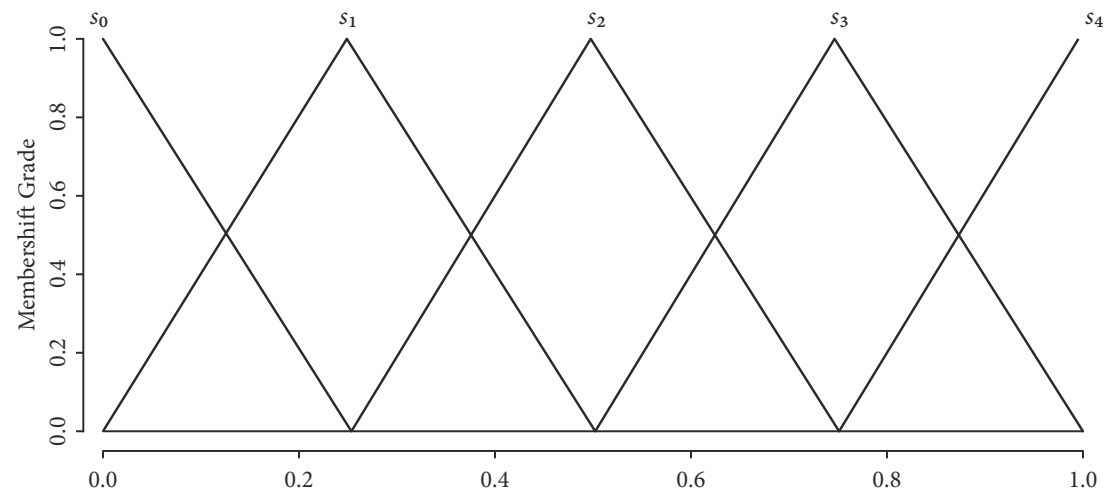

Figure 3. Example of definition of a 5-Likert scale using a fuzzy linguistic model: $s_{0}=$ strongly disagree $=S D, s_{1}=$ disagree $=D, s_{2}=$ neither agree nor disagree $=N$, $s_{3}=$ agree $=A, s_{4}=$ strongly agree $=S A$

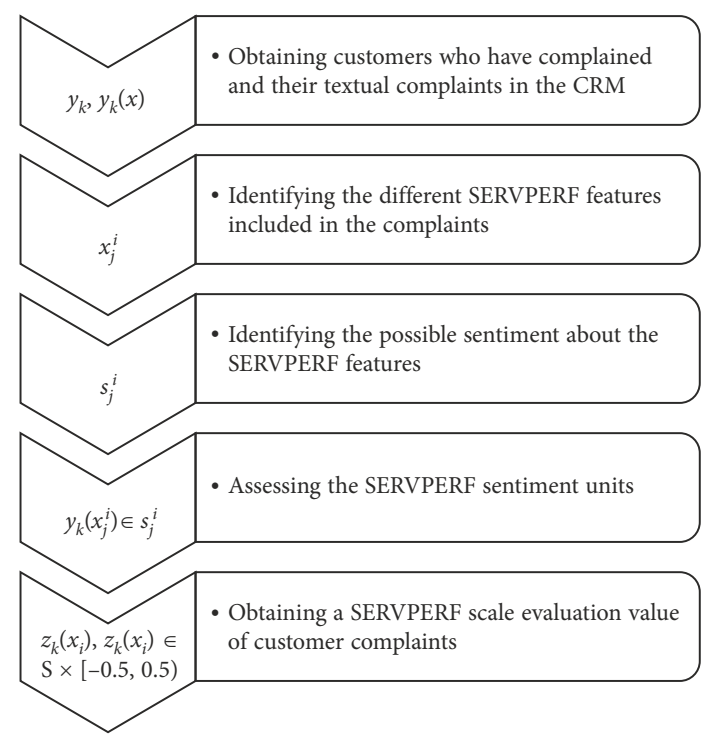

Figure 4. Model to obtain a 2-tuple SERVPERF scale evaluation of the customer's complaints

\subsection{Obtaining customers who have complained and their textual complaints in the CRM}

In the CRM terminology, trouble tickets (Piepiorra, 2015) or cases (Snyder, Steger, \& Landers, 2011) are any kind of customer service requests or complaints as they occur after sales. Therefore, at this stage, we need to identify the tickets containing the customer complaints. Normally, this is easy because the tickets often contain a field that categorizes its type.

We represent this set of customers as $Y=\left\{y_{1}, \ldots, y_{m}\right\}$, such that each of them has made at least one complaint. Complaints by these customers are expressed in natural language in the corresponding CRM tickets, considering that $y_{k}(x), \forall k \in\{1, \ldots, m\}$ contains these complaints corresponding to the customer $y_{k}$ in a given period of time. 


\subsection{Identifying the different SERVPERF features included in the complaints}

A SERVPERF feature $x_{j}^{i}, i \in\{1, \ldots, n\}, n=5, j \in\left\{1, \ldots, \# S P_{i}\right\}$ is a/some word/s symbolizing the perception by the user of a particular characteristic corresponding to a SERVPERF scale, $P_{i}$, which underlies the question $x_{j}{ }^{i}$ in Table 1.

Therefore, this step aims to identify these features of services (on which customers focus their complaints), that could be included in $y_{k}(x)$.

Example 2. As seen in Section 1.2, customers perceive the reliability dimension, i.e., $P_{2}$, through aspects such as network signal stability and coverage (question $q_{1}^{2}$ in Table 1) and ease of configuration of the network or terminals (question $q_{3}^{2}$ in Table 1). Therefore, two SERVPERF features for this scale could be:

$$
x_{1}^{2}=\text { Coverage, } x_{3}^{2}=\text { Configuration }
$$

\subsection{Identifying the possible sentiment about the SERVPERF features}

A sentiment about a SERVPERF feature is a word or set of words that conveys the main notion of the assessment of the feature. In other words, it is the domain in which the sentiment is expressed.

This stage provides the possible sentiments of these SERVPERF features expressed in natural language in the corresponding complaints. For each feature, $x_{j}^{i}$, we define the linguistic term set with $t$ possible basic sentiments about such a feature, $T_{j}^{i}=\left\{s_{0 j}{ }^{i}, \ldots, s_{t j}{ }^{i}\right\}$, with the same characteristics of set $T$ that are used to express the results of our system.

Finally, we define the domain of a possible sentiment about the feature $x_{j}^{i}$ with all the linguistic terms defined, adding their corresponding negative term, i.e., $S_{j}^{i}=\left\{\left(s_{0 j}{ }^{i}, 0\right), \ldots\right.$, $\left(s_{t j}{ }^{i}, 0\right)$, neg $\left.\left(\left(s_{0 j}{ }^{i}, 0\right)\right), \ldots, n e g\left(\left(s_{t j}{ }^{i}, 0\right)\right)\right\}$, using the operator $n e g()$ defined in Eq. (3). We have used the 2-tuple model explained in Section 1.1 to define this set. Each element of the set has the value 0 as a symbolic translation but the great advantage of this representation is that no subsequent calculations with these elements will lose information.

Example 3. Following Example 2, we could define the characteristics shown below:

- Coverage: $s_{01}^{2}=$ very bad, $s_{11}^{2}=$ bad, $s_{21}^{2}=$ average, $s_{31}^{2}=$ good, $s_{41}^{2}=$ very good.

- Configuration: $s_{02}{ }^{2}=$ very complicated, $s_{13}{ }^{2}=$ complicated, $s_{23}{ }^{2}=$ average, $s_{33}{ }^{2}=$ easy, $s_{43}^{2}=$ very easy.

\subsection{Assessing the SERVPERF sentiment units}

Based on the idea of sentiment unit explained in Section 1.3, at this stage we introduce the SERVPERF sentiment units, which relate the SERVPERF features with their sentiment identified in the CRM complaints. In other words, this unit contains the categorized SERVPERF features with their corresponding sentiments. We symbolize them with $y_{k}\left(x_{j}^{i}\right) \in S_{j}^{i}, \forall k \in$ $\{1, \ldots, m\}, \forall i \in\{1, \ldots, n\}, \forall j \in\left\{1, \ldots, \# S P_{i}\right\}$ as the subjective opinion provided by the user $y_{k}$ about the feature $x_{j}^{i}$ (belonging to the SERVPERF scales $P_{i}$ ) i.e., the user's assessment or perception of this feature expressed with set $S_{j}^{i}$. This step defines a method to extract each $y_{k}\left(x_{j}^{i}\right)$ from the complaint tickets expressed in natural language, i.e., from $y_{k}(x)$. 
We proceed to define the representation of our model as a set of the production rules defined in BNF (Figure 5) in order to extract the $y_{k}\left(x_{j}^{i}\right) \in S_{j}^{i}$ (sentiment unit assessment) from the $y_{k}(x)$ (natural language).

Thus, a <complaint ticket $>$ consists of one or more $<$ servperf sentiment unit $>$ and a $<$ surface ticket $>$ in natural language $\left(y_{k}(x)\right)$. Each of these sentiment units consists of a $<$ servperf features $>\left(x_{j}^{i}\right)$ qualified by a $<$ sentiment $>\left(s_{r j}{ }^{i}, r \in\{0, \ldots, t\}\right)$. In addition, the sentiment could be qualified by a $<$ negative sentiment $>$, which becomes a negative sentiment. In this case, the assessment of SERVPERF sentiment unit is $y_{k}\left(x_{j}^{i}\right)=n e g\left(\left(s_{r j}{ }^{i}, 0\right)\right)$, using the negation operator defined in Eq. (3). If we have not identified this negative sentiment, the assessment is $y_{k}\left(x_{j}^{i}\right)=\left(s_{r j}{ }^{i}, 0\right)$.

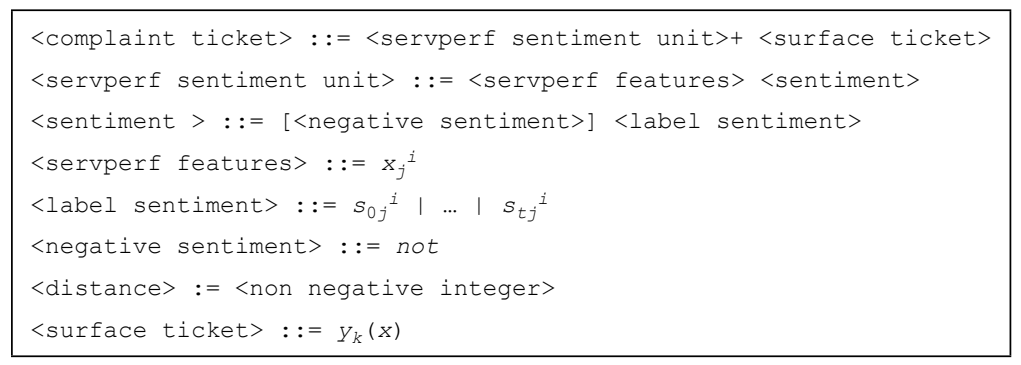

Figure 5. BNF definition of a complaint ticket

If we relate the sentiment unit, proposed by Hiroshi et al. (2004) and explained in Section 1.3, to our SERVPERF sentiment unit, then the SERVPERF features would correspond to the arguments. However, the domain in which the sentiment about the features is expressed is different in our case, because it not only has two values (favourable and unfavourable) but is also modelled with several linguistic terms with fuzzy semantics. Such linguistic labels could be identified in the corresponding predicate. Using the idea of surface form, we have defined the surface ticket as the part of the complaint in the original text $y_{k}(x)$. In Table 3 , we present a summary of this comparison.

Table 3. Sentiment unit (Hiroshi et al., 2004) vs. SERVPERF sentiment unit

\begin{tabular}{|l|l|l|}
\hline & \multicolumn{1}{|c|}{ Sentiment unit } & \multicolumn{1}{c|}{ SERVPERF sentiment unit } \\
\hline Purpose & global sentiment analysis & $\begin{array}{l}\text { perception of quality according } \\
\text { to the SERVPERF scales }\end{array}$ \\
\hline Original text to evaluate & surface form & surface ticket: $y_{k}(x)$ \\
\hline Object to evaluate & arguments & SERVPERF features: $x_{j}^{i}$ \\
\hline $\begin{array}{l}\text { Sentiment unit } \\
\text { assessment }\end{array}$ & $\begin{array}{l}\text { predicate assessment } \in\{\text { favourable, } \\
\text { unfavourable, question, request }\}\end{array}$ & $y_{k}\left(x_{j}^{i}\right) \in S_{j}^{i}$ \\
\hline
\end{tabular}

Example 4. We might find the following complaint in a CRM trouble ticket expressed by the customer $y_{1}$ :

$y_{1}(x)=$ "The client tells us that the modem configuration was not easy, moreover once finished, coverage is very bad." 
This complaint contains two SERVPERF sentiment units: the first one, whose assessment is obtained by applying the negation operator; and the second one with no identified negation operator. These units are shown below:
1. $x_{2}{ }^{3}=$ Configuration, $y_{1}\left(x_{2}{ }^{3}\right)=\operatorname{not}(($ easy, 0$))=($ complicated, 0$)=\left(s_{13}{ }^{2}, 0\right)$;
2. $x_{2}{ }^{1}=$ Coverage, $y_{1}\left(x_{2}{ }^{1}\right)=($ very bad, 0$)=\left(s_{01}{ }^{2}, 0\right)$.

\subsection{Obtaining a SERVPERF scale evaluation value of customer complaints}

Based on the assessment of the SERVPERF sentiment unit obtained in the previous phase, the aim is to obtain the complaint assessment on each SERVPERF scale. This must be achieved in two phases; in the first one, we obtain this assessment for each client, i.e., at the client level; in the second phase, we obtain an overall SERVPERF scale evaluation value of customer complaints.

For our first objective, the 2-tuple arithmetic mean operator $\bar{A}^{e}$ defined in Eq. (4) is used to obtain the complaint assessment of each SERVPERF scale $P_{i}$ for each client $y_{k}$ :

$$
z_{k}\left(x_{i}\right)=\bar{A}^{e}\left[y_{k}\left(x_{j}^{i}\right)\right], \forall k \in\{1, \ldots, m\}, \forall i \in\{1, \ldots, n\}, n=5, \forall j \in\left\{1, \ldots, \# S P_{i}\right\} .
$$

These result are 2 -tuple values, i.e., $z_{k}\left(x_{i}\right) \in T \times[-0.5,0.5)$, computed without loss of information.

Example 5. In order to obtain the complaint assessment of the SERVPERF scales $P_{2}$ for customer $y_{1}$ (Example 4) we apply Eq. (5):

$$
z_{1}\left(x_{2}\right)=\bar{A}^{e}\left[y_{1}\left(x_{2}{ }^{3}\right), y_{1}\left(x_{2}{ }^{1}\right)\right]=\bar{A}^{e}\left[\left(s_{13}^{2}, 0\right),\left(s_{01}^{2}, 0\right)\right]=(D,-0.5) .
$$

This means that the assessment of reliability of client $y_{1}$ on the SERVPERF scale is strongly disagree minus 0.5 .

Again, we use the operator $\bar{A}^{e}$ to obtain an overall evaluation of each SERVPERF scale $P_{i}$ for all customer complaints:

$$
z\left(x_{i}\right)=\bar{A}^{e}\left[z_{k}\left(x_{i}\right)\right], \forall k \in\{1, \ldots, m\}, \forall i \in\{1, \ldots, n\}, n=5 .
$$

Once more, these results are 2-tuple values, i.e., $z\left(x_{i}\right) \in T \times[-0.5,0.5)$, computed without loss of information.

It should be noted that we have available the SERVPERF assessment, $z_{k}\left(x_{i}\right)$, for each CRM customer. Thus, we could take this last aggregation step by grouping by any dimension related to the customer, available in the CRM. For example, we could obtain SERVPERF evaluations at several levels: customer segment, age, geographic location, etc.

\section{Applying the SERVPERF evaluation of the customer complaints model to A 4G service company}

In this section, we present an example of an application of our SERVPERF evaluation of the customer complaints model, explained in the above section, using the CRM information of Clearwire, to a $4 \mathrm{G}$ Multinational Service Company located in Europe. 
First we chose the scale that will express the output results, i.e., the SERVPERF scale evaluation. In our case, we decided to use a 5 -Likert scale, i.e., $t=4$. In Figure 1 , we presented a definition of this scale.

Next, we will explain the different stages that comprise our model (see Figure 2):

\section{Obtaining customers who have complained and their textual complaints in the CRM}

Based on information from the CRM included in the corporate data warehouse, we obtain all the trouble tickets that we believe may contain a customer complaint. Thus, we select all the information stored on tickets where the field TROUBLETICKET_TYPE contains any value of the set $\{$ Incident, Claim, Deactivation Request $\}$. We discard those tickets that do not contain textual information about the claim made by the customer.

A total of 82511 trouble tickets were selected, corresponding to 60534 clients. We consider that $y_{k}(x), \forall k \in\{1, \ldots, m\}, m=60534$ contain these complaints, expressed in natural language, corresponding to the customer $y_{k}$.

\section{Identifying the different SERVPERF features included in the complaints and their possible sentiment}

Performing a process of text mining on the textual complaints, $y_{k}(x)$, we obtain the most frequently used words and expressions related to the questions in Table 1. After analysing them, we obtain both the features associated with different SERVPERF scales, $x_{j}{ }^{i}$, and their possible sentiment, $s_{r j}{ }^{i}$. In Table 4 , we show an extract of these features and potential associated sentiments.

Table 4. An extract of the features and potential associated sentiments identified in the CRM.

\begin{tabular}{|l|l|l|l|l|l|l|l|}
\hline$x_{j}{ }^{i}$ & \multicolumn{1}{|c|}{ Feature } & $\begin{array}{l}\text { SERVPERF } \\
\text { Scale }\end{array}$ & \multicolumn{1}{|c|}{$s_{0 j}{ }^{i}$} & \multicolumn{1}{c|}{$s_{1 j}{ }^{i}$} & \multicolumn{1}{|c|}{$s_{2 j}{ }^{i}$} & \multicolumn{1}{|c|}{$s_{3 j}{ }^{i}$} & \multicolumn{1}{|c|}{$s_{4 j}{ }^{i}$} \\
\hline$x_{1}{ }^{1}$ & Download & Tangibles & very slow & slow & average & fast & very fast \\
\hline$x_{2}{ }^{1}$ & Upload & Tangibles & very slow & slow & average & fast & very fast \\
\hline$x_{3}{ }^{1}$ & Browse & Tangibles & very bad & bad & average & good & very good \\
\hline$x_{4}{ }^{1}$ & Video & Tangibles & very slow & slow & average & fast & very fast \\
\hline$x_{5}{ }^{1}$ & Connection & Tangibles & very bad & bad & average & good & very good \\
\hline$x_{6}{ }^{1}$ & Speed & Tangibles & very slow & slow & average & fast & very fast \\
\hline$x_{1}{ }^{2}$ & Coverage & Reliability & very bad & bad & average & good & very good \\
\hline$x_{2}{ }^{2}$ & Signal & Reliability & $\begin{array}{l}\text { very un- } \\
\text { stable }\end{array}$ & unstable & average & stable & very stable \\
\hline$x_{3}{ }^{2}$ & Configuration & Reliability & $\begin{array}{l}\text { very com- } \\
\text { plicated }\end{array}$ & $\begin{array}{l}\text { compli- } \\
\text { cated }\end{array}$ & average & easy & very easy \\
\hline$x_{4}{ }^{2}$ & Update & Reliability & $\begin{array}{l}\text { very com- } \\
\text { plicated }\end{array}$ & $\begin{array}{l}\text { compli- } \\
\text { cated }\end{array}$ & average & easy & very easy \\
\hline$x_{1}{ }^{3}$ & Issue & $\begin{array}{l}\text { Responsive- } \\
\text { ness }\end{array}$ & $\begin{array}{l}\text { fully un- } \\
\text { solved }\end{array}$ & unsolved & $\begin{array}{l}\text { partially } \\
\text { solved }\end{array}$ & solved & fully solved \\
\hline$x_{2}{ }^{3}$ & Request & ness & $\begin{array}{l}\text { fully un- } \\
\text { solved }\end{array}$ & unsolved & $\begin{array}{l}\text { partially } \\
\text { solved }\end{array}$ & solved & fully solved \\
\hline
\end{tabular}


End of Table 4

\begin{tabular}{|l|l|l|l|l|l|l|l|}
\hline$x_{j}^{i}$ & \multicolumn{1}{|c|}{ Feature } & \multicolumn{1}{|c|}{$\begin{array}{l}\text { SERVPERF } \\
\text { Scale }\end{array}$} & \multicolumn{1}{c|}{$s_{0 j}{ }^{i}$} & \multicolumn{1}{c|}{$s_{1 j}{ }^{i}$} & \multicolumn{1}{c|}{$s_{2 j}{ }^{i}$} & \multicolumn{1}{c|}{$s_{3 j}{ }^{i}$} & \multicolumn{1}{c|}{$s_{4 j^{i}}$} \\
\hline$x_{3}{ }^{3}$ & Complaint & $\begin{array}{l}\text { Responsive- } \\
\text { ness }\end{array}$ & $\begin{array}{l}\text { fully un- } \\
\text { solved }\end{array}$ & unsolved & $\begin{array}{l}\text { partially } \\
\text { solved }\end{array}$ & solved & fully solved \\
\hline$x_{4}{ }^{3}$ & $\begin{array}{l}\text { Required in- } \\
\text { formation }\end{array}$ & $\begin{array}{l}\text { Responsive- } \\
\text { ness }\end{array}$ & $\begin{array}{l}\text { fully un- } \\
\text { provided }\end{array}$ & $\begin{array}{l}\text { unpro- } \\
\text { vided }\end{array}$ & $\begin{array}{l}\text { partially } \\
\text { provided }\end{array}$ & provided & $\begin{array}{l}\text { fully pro- } \\
\text { vided }\end{array}$ \\
\hline$x_{1}{ }^{4}$ & $\begin{array}{l}\text { Network out- } \\
\text { ages }\end{array}$ & Assurance & $\begin{array}{l}\text { very fre- } \\
\text { quent }\end{array}$ & frequent & $\begin{array}{l}\text { some- } \\
\text { times }\end{array}$ & rare & never \\
\hline$x_{2}{ }^{4}$ & Dropped calls & Assurance & $\begin{array}{l}\text { very fre- } \\
\text { quent }\end{array}$ & frequent & $\begin{array}{l}\text { some- } \\
\text { times }\end{array}$ & rare & never \\
\hline$x_{3}{ }^{4}$ & $\begin{array}{l}\text { Failed down- } \\
\text { loads }\end{array}$ & Assurance & $\begin{array}{l}\text { very fre- } \\
\text { quent }\end{array}$ & frequent & $\begin{array}{l}\text { some- } \\
\text { times }\end{array}$ & rare & never \\
\hline$x_{4}{ }^{4}$ & Failed uploads & Assurance & $\begin{array}{l}\text { very fre- } \\
\text { quent }\end{array}$ & frequent & $\begin{array}{l}\text { some- } \\
\text { times }\end{array}$ & rare & never \\
\hline$x_{1}{ }^{5}$ & $\begin{array}{l}\text { Provided in- } \\
\text { formation }\end{array}$ & Empathy & $\begin{array}{l}\text { fully incor- } \\
\text { rect }\end{array}$ & incorrect & $\begin{array}{l}\text { partially } \\
\text { correct }\end{array}$ & correct & fully correct \\
\hline$x_{2}{ }^{5}$ & Treatment & Empathy & very bad & bad & normal & good & very good \\
\hline$x_{3}{ }^{5}$ & Staff & Empathy & $\begin{array}{l}\text { very un- } \\
\text { friendly }\end{array}$ & $\begin{array}{l}\text { unfriend- } \\
\text { ly }\end{array}$ & $\begin{array}{l}\text { partially } \\
\text { friendly }\end{array}$ & friendly & very friendly \\
\hline
\end{tabular}

\section{Assessing the SERVPERF sentiment units}

In order to identify sentiment units and obtain the assessment of the unit, $y_{k}\left(x_{j}^{i}\right)$, we must implement the production rules defined in Figure 4. Basically, we have to find within the same semantic unit (sentence or phrase portion $y_{k}(x)$ ) some sentiment, $s_{r j}{ }^{i}$, about any of the associated features, $x_{j}^{i}$, both identified in the previous phases. The extraction of these sentiment units is not a trivial task because many syntactic and semantic operations are required. As an approach to this process, we proceed to define the representation of our model as a set of the production rules defined in an extended BNF (Elkhalifa, Adaikkalavan, \& Chakravarthy, 2005). Formally, it is expressed as in Figure 6.

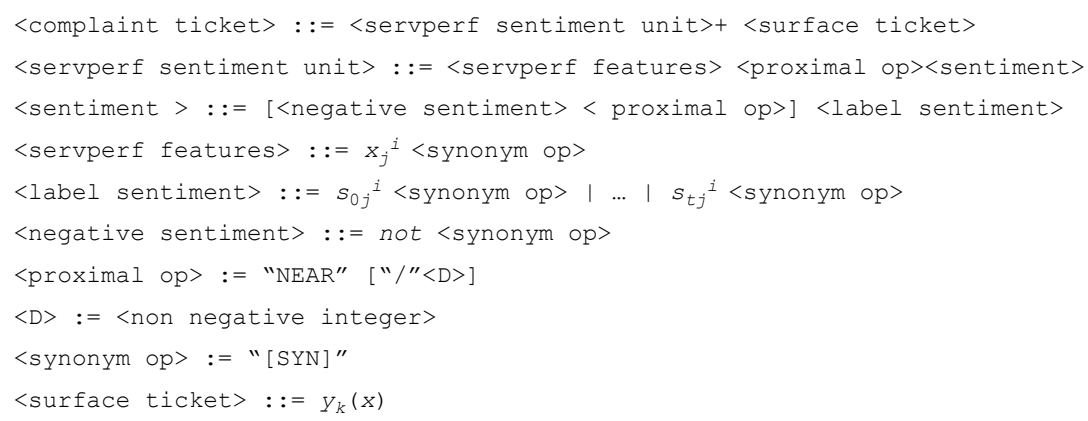

Figure 6. The definition of a complaint ticket 
According to this definition, each of the sentiment units $<$ servperf sentiment unit $>$ consists of a $<$ servperf features $>$ close to a $<$ sentiment $>$. The closeness of the two entities or patterns implies that the basic sentiment $s_{r j}{ }^{i}, r \in\{0, \ldots, t\}$, qualifies the feature $\left(x_{j}^{i}\right)$. The closeness is modelled using the NEAR operator (Elkhalifa et al., 2005): a conjunction of two simple or complex patterns, $P 1=s_{r j}{ }^{i}$ and $P 2=x_{j}{ }^{i}$, denoted by $P 1$ NEAR [/D] $P 2$, occurs when both $P 1$ and $P 2$ occur, regardless of their order of occurrence. $D$ is the maximum distance allowed between patterns $P 1$ and $P 2$, always within the same semantic unit (sentence or phrase portion). The default value of $D$ is the whole semantic unit. For example, "speed" NEAR/4 "slow" will be detected whenever both these words co-occur within a distance of 4 words.

Both features of such a sentiment can have multiple forms (synonyms, abbreviations...) so we use the [SYN] operator (Elkhalifa et al., 2005) to identify them. For example, we specify the word "speed"[SYN] is equivalent to "speed", "velocity", "celerity", "fastness", "quickness", etc.

The sentiment may have close words that turn into a negative sentiment; in this case, the assessment of the SERVPERF sentiment unit is $y_{k}\left(x_{j}^{i}\right)=n e g\left(\left(s_{r j}{ }^{i}, 0\right)\right)$. These negative particles can also have multiple forms, so we again use "not" [SYN] for this identification. If we have not identified this negative sentiment, the assessment is $y_{k}\left(x_{j}^{i}\right)=\left(s_{r j}{ }^{i}, 0\right)$.

Oracle Text (Shea, Faisal, Ford, Lin, \& Matsuda, 2008) has been used as a tool to implement such production rules (Figure 6). In particular, we use the Oracle Text contains and near operators (Shea et al., 2008) to implement the NEAR operator to identify the proximity of the two patterns searched (feature and sentiment) and/or the proximity of the words that turn sentiment into negative sentiment. In order to implement the [SYN] operator, we use some specialized thesaurus of terms comprised of: synonyms that include formal and informal terms and abbreviators; higher level terms; and words that have the same root as the specified term, using the stem operator (Shea et al., 2008). Moreover, we improve the [SYN] operator to find more precise results when there are many misspellings in the CRM textual customer complaints: words that sound like the specified terms, identified with the soundex operator (Shea et al., 2008) and words that are spelled the same as the specified terms, recognised with the fuzzy operator (Shea et al., 2008).

Performing the implemented process on the textual complaints, $y_{k}(x)$, using the features and associated sentiments identified in the previous step (Table 4), we obtain the SERVPERF sentiment units and their assessment for each client $y_{k}$. In Table 5, we present an extract of these results. In order to make clearer the values used for linguistic term conversion to linguistic 2-tuple, in the texts included in Table 5, the features are written in boldface and the sentiment in italics.

\section{Obtaining the SERVPERF scale evaluation of customer complaints}

As explained, the Eq. (5) is used to obtain the SERVPERF scale evaluation, $z_{k}\left(x_{i}\right)$, for each client, $y_{k}$, and for each scale, $P_{i}$. In Table 6, we show an extract of these results for the customer and assessments of the SERVPERF sentiment units included in Table 5. As can be seen, for the customers identified as 55518 and 568008 (they have more than one assessment of features that belong to the same scale), owing to the 2-tuple model, this aggregation process is carried out without any loss of information. 
Table 5. An extract of the assessments of SERVPERF sentiment units

\begin{tabular}{|c|c|c|c|c|}
\hline$y_{k}$ & $\begin{array}{l}\text { Call } \\
\text { Type }\end{array}$ & $y_{k}(x)$ & $x_{j}$ & $y_{k}\left(x_{j}^{i}\right)$ \\
\hline 562379 & $\begin{array}{c}\text { Out- } \\
\text { bound }\end{array}$ & $\begin{array}{l}\text { Customer wants to cancel because of } \\
\text { bad coverage in the house so she can't } \\
\text { browse correctly. I remind her that we } \\
\text { offered to install outdoor antenna for } \\
\text { better coverage, but she didn't call back. } \\
\text { I offer a discount tariff of } 19.90 € \text { for } 6 \\
\text { months after installing outdoor antenna } \\
\text { and she accepts. }\end{array}$ & $\begin{array}{l}\text { "coverage" } \\
{[\text { SYN] }} \\
=\text { Coverage } \\
\text { "browse" } \\
{[\text { SYN] }} \\
=\text { Browse }\end{array}$ & $\begin{array}{l}\text { (“bad" [SYN] ,0) } \\
=(\text { bad, } 0)=\left(s_{11}{ }^{2}, 0\right) \\
\text { "can't" [SYN] } \\
\text { (("correctly" [SYN],0)) } \\
=\operatorname{not}((\operatorname{good}, 0)) \\
\left.=(\text { bad }, 0)=\left(s_{13}{ }^{1}, 0\right)\right)\end{array}$ \\
\hline 556741 & $\begin{array}{c}\text { Out- } \\
\text { bound }\end{array}$ & $\begin{array}{l}\text { Sales channel requests cancelling the } \\
\text { service because customer received } \\
\text { incorrect information regarding } \\
\text { coverage areas. Customer doesn't want } \\
\text { to cancel, but we inform that it is not } \\
\text { possible to provide a good service. We } \\
\text { process cancellation without penalty. } \\
\text { Customer agrees. We deactivate. }\end{array}$ & $\begin{array}{l}\text { "received } \\
\text { information" } \\
\text { [SYN] } \\
\text { = Provided } \\
\text { information }\end{array}$ & $\begin{array}{l}\text { (“incorrect" [SYN], 0) } \\
=(\text { incorrect }, 0) \\
\left.=\left(s_{11} 5,0\right)\right)\end{array}$ \\
\hline 558797 & $\begin{array}{c}\text { In- } \\
\text { bound }\end{array}$ & $\begin{array}{l}\text { Customer wants deactivation. She } \\
\text { complains about the service. We have } \\
\text { verified technical data: has saturated } \\
\text { BTS. She uses the service for Play } \\
\text { Station } 3 \text { games online, YouTube. I } \\
\text { explain that the contract is } 1-3 \mathrm{Mb} \text {. She } \\
\text { feels tricked by the seller because he } \\
\text { said it would have more speed, and } \\
\text { she told him about their use of online } \\
\text { games. She also says slow speed when } \\
\text { opening any page in Internet. We offer a } \\
\text { Save agent visit. }\end{array}$ & $\begin{array}{l}\text { "seller” [SYN] } \\
=\text { Staff } \\
\text { “speed” [SYN] } \\
=\text { Speed }\end{array}$ & $\begin{array}{l}\text { ("tricked" [SYN], } 0) \\
=(\text { very unfriendly }, 0) \\
\left.=\left(s_{03} 5,0\right)\right) \\
\text { ("slow" }[\mathrm{SYN}], 0) \\
\left.=(\text { slow }, 0)=\left(s_{16}{ }^{1}, 0\right)\right)\end{array}$ \\
\hline 557444 & $\begin{array}{c}\text { In- } \\
\text { bound }\end{array}$ & $\begin{array}{l}\text { Customer requests cancelling the } \\
\text { service. At first, was only the phone } \\
\text { service but now he wants to cancel } \\
\text { the Internet access too. I ask why and } \\
\text { he says it is not acceptable to wait for } \\
12 \text { days without solution to his claim } \\
\text { of being unable to make calls and we } \\
\text { didn't even call him to inform how we } \\
\text { were managing the situation. First, I } \\
\text { apologize and try to find out whether } \\
\text { the issue is solved and he says he doesn't } \\
\text { know because he has disconnected the } \\
\text { phone, ready to send it back. }\end{array}$ & $\begin{array}{l}\text { "claim" [SYN] } \\
=\text { Issue }\end{array}$ & $\begin{array}{l}\text { "without" [SYN] } \\
((\text { "solution" [SYN], 0)) } \\
=\text { not }((\text { solved, } 0) \\
=(\text { unsolved }, 0) \\
\left.=\left(s_{11}{ }^{3}, 0\right)\right)\end{array}$ \\
\hline 560698 & $\begin{array}{c}\text { In- } \\
\text { bound }\end{array}$ & $\begin{array}{l}\text { Customer requests cancelling the } \\
\text { service. I ask the reason why and he } \\
\text { says the connection is very bad and } \\
\text { with frequent power cuts. We arrange } \\
\text { an appointment with Save agent } \\
\text { tomorrow to solve the issue. Customer } \\
\text { agrees to continue, has no permanence. }\end{array}$ & $\begin{array}{l}\text { "connection" } \\
\text { [SYN] } \\
\text { = Connection } \\
\text { "power cuts" } \\
\text { [SYN] } \\
\text { = Network } \\
\text { outages }\end{array}$ & $\begin{array}{l}\text { ("very bad" [SYN], 0) } \\
=(\text { very bad }, 0) \\
\left.=\left(s_{05}{ }^{1}, 0\right)\right) \\
\text { ("frequent" [SYN], } 0) \\
=(\text { frequent }, 0) \\
\left.=\left(s_{11}{ }^{4}, 0\right)\right)\end{array}$ \\
\hline
\end{tabular}


1624 R. A. Carrasco et al. A model to obtain a SERVPERF scale evaluation of the CRM customer complaints ...

End of Table 5

\begin{tabular}{|c|c|c|c|c|}
\hline$y_{k}$ & $\begin{array}{l}\text { Call } \\
\text { Type }\end{array}$ & $y_{k}(x)$ & $x_{j}$ & $y_{k}\left(x_{j}^{i}\right)$ \\
\hline 559907 & $\begin{array}{c}\text { In- } \\
\text { bound }\end{array}$ & $\begin{array}{l}\text { Ana, the customer's wife, calls. } \\
\text { Coverage light green / yellow. Cable } \\
\text { connection. firmware_version_1: } \\
\text { ESP_IX380V1.0.0C13. Computer } \\
\text { doesn't have antivirus. She complains } \\
\text { about slow navigation. They also have } \\
\text { some conversation cuts when using } \\
\text { the phone service: in the middle of the } \\
\text { conversation or else they can't contact, } \\
\text { either outgoing or incoming calls. We } \\
\text { try to make speed test in safe mode, but } \\
\text { it is not possible, so we do it in normal } \\
\text { mode: } 1906 \text { kbps download and } 236 \\
\text { kbps. }\end{array}$ & $\begin{array}{l}\text { "navigation" } \\
{[S Y N]=} \\
\text { Browse } \\
\text { "conversation } \\
\text { cuts" [SYN] } \\
=\text { Dropped } \\
\text { calls }\end{array}$ & $\begin{array}{l}\text { ("slow" [SYN], 0) } \\
\left.=(\text { bad }, 0)=\left(s_{13}{ }^{1}, 0\right)\right) \\
\text { ("some" [SYN], } 0) \\
=(\text { sometimes, } 0) \\
=\left(s_{22}^{4}, 0\right)\end{array}$ \\
\hline 555108 & $\begin{array}{c}\text { In- } \\
\text { bound }\end{array}$ & $\begin{array}{l}\text { Customer calls because the service } \\
\text { is very slow in download and when } \\
\text { browsing. I inform of p2p policy. He is } \\
\text { not in front of computer. I inform him } \\
\text { to call then. }\end{array}$ & $\begin{array}{l}\text { "Download" } \\
\text { [SYN] } \\
\text { = Download } \\
\text { "browsing" } \\
\text { [SYN] } \\
\text { = Browse }\end{array}$ & $\begin{array}{l}\text { ("very slow" [SYN], 0) } \\
=(\text { very slow }, 0) \\
\left.=\left(s_{01}{ }^{1}, 0\right)\right) \\
\text { ("very slow" }[\mathrm{SYN}], 0) \\
=(\text { very bad }, 0) \\
\left.=\left(s_{03}{ }^{1}, 0\right)\right)\end{array}$ \\
\hline 553355 & $\begin{array}{l}\text { Out- } \\
\text { bound }\end{array}$ & $\begin{array}{l}\text { We proceed to cancel by Save agent } \\
\text { request- technical issue. Reason: } \\
\text { unstable signal, incidence } 545,759 \text { sent } \\
\text { from the } 22 / 03 \text { front, client does not } \\
\text { want commercial offer. }\end{array}$ & $\begin{array}{l}\text { "signal" [SYN] } \\
=\text { Signal }\end{array}$ & $\begin{array}{l}\text { (“unstable" [SYN],0) } \\
=(\text { unstable }, 0) \\
\left.=\left(s_{12}{ }^{2}, 0\right)\right)\end{array}$ \\
\hline 555076 & $\begin{array}{c}\text { In- } \\
\text { bound }\end{array}$ & $\begin{array}{l}\text { Customer says the service fails when } \\
\text { installing the modem upgrade. } \\
\text { Indicates that he has already installed } \\
\text { java, and it produces errors. He will } \\
\text { reset the modem and call us after he } \\
\text { tries again. }\end{array}$ & $\begin{array}{l}\text { "installing" } \\
{[\mathrm{SYN}]} \\
=\text { Configura- } \\
\text { tion }\end{array}$ & $\begin{array}{l}\text { (“fails" [SYN],0) } \\
=(\text { complicated }, 0) \\
\left.=\left(s_{13}{ }^{2}, 0\right)\right)\end{array}$ \\
\hline 568008 & $\begin{array}{c}\text { In- } \\
\text { bound }\end{array}$ & $\begin{array}{l}\text { Customer calls and points out that } \\
\text { incidence } 540887 \text { is not solved yet. } \\
\text { When she has required information, } \\
\text { this has been provided partially but she } \\
\text { doesn't know who the solution depends } \\
\text { on. }\end{array}$ & \begin{tabular}{|l} 
"incidence" \\
[SYN] = Issue \\
\\
"required \\
information" \\
{$[$ SYN $]$} \\
$=$ Required \\
information
\end{tabular} & $\begin{array}{l}\text { "not" [SYN] ((“solved" } \\
\text { [SYN] }), 0) \\
=\text { not }((\text { solved }, 0)) \\
=(\text { unsolved }, 0) \\
\left.=\left(s_{11}^{3}, 0\right)\right) \\
\text { ("provided partially" } \\
[\text { SYN }], 0) \\
=(\text { partially } \\
\left.\text { provided }, 0)=\left(s_{24}{ }^{3}, 0\right)\right)\end{array}$ \\
\hline
\end{tabular}

Finally, applying Eq. (6), we obtain the overall SERVPERF evaluation of all CRM complaints. We present these results in Table 7, including the percentage of complaints identified for each scale out the total of complaints. 
Table 6. An extract of the SERVPERF scale evaluation of customer complaints

\begin{tabular}{|c|c|c|c|c|c|}
\hline$y_{k}$ & $\begin{array}{c}z_{k}\left(x_{1}\right) \\
\text { Tangibles }\end{array}$ & $\begin{array}{c}z_{k}\left(x_{2}\right) \\
\text { Reliability }\end{array}$ & $\begin{array}{c}z_{k}\left(x_{3}\right) \\
\text { Responsiveness }\end{array}$ & $\begin{array}{c}z_{k}\left(x_{4}\right) \\
\text { Assurance }\end{array}$ & $\begin{array}{c}z_{k}\left(x_{5}\right) \\
\text { Empathy }\end{array}$ \\
\hline 562379 & $(\mathrm{D}, 0)$ & $(\mathrm{D}, 0)$ & & & \\
\hline 556741 & & & & & $(\mathrm{D}, 0)$ \\
\hline 558797 & $(\mathrm{D}, 0)$ & & & & $(\mathrm{SD}, 0)$ \\
\hline 557444 & & & $(\mathrm{D}, 0)$ & & \\
\hline 560698 & $(\mathrm{SD}, 0)$ & & & $(\mathrm{D}, 0)$ & \\
\hline 559907 & $(\mathrm{D}, 0)$ & & & $(\mathrm{N}, 0)$ & \\
\hline 555108 & $(\mathrm{SD}, 0)$ & & & & \\
\hline 553355 & & $(\mathrm{D}, 0)$ & & & \\
\hline 555076 & & $(\mathrm{D}, 0)$ & & & \\
\hline 568008 & & & $(\mathrm{~N},-0.5)$ & & \\
\hline
\end{tabular}

Table 7. Overall SERVPERF scale evaluation of customer complaints and percentage of total complaints.

\begin{tabular}{|c|c|c|c|c|c|}
\hline & Tangibles & Reliability & Responsiveness & Assurance & Empathy \\
\hline$z\left(x_{i}\right)$ & $(\mathrm{D},-0.044)$ & $(\mathrm{D},-0.039)$ & $(\mathrm{SD},+0.067)$ & $(\mathrm{D},-0.047)$ & $(\mathrm{SD},+0.082)$ \\
\hline$\%$ Total & $6.78 \%$ & $6.51 \%$ & $1.78 \%$ & $5.54 \%$ & $1.83 \%$ \\
\hline
\end{tabular}

If we analyse the claims in which no SERVPERF assessment was identified, we found that most of these claims do not have a customer rating, i.e., they have only annotations on the internal processes of the company. In some cases, customers focus their complaints on services through the trade name. Therefore, the business portfolio of the company should be included in the feature set $\left\{x_{j}^{i}\right\}$. In general, most complaints are related to the technical aspects of services: tangibles $(6.78 \%)$, reliability $(6.51 \%)$ and assurance (5.54\%). Few are related to staff: responsiveness (1.78\%) and empathy (1.83\%). Precisely these two scales are the worst valued by customers, whereas reliability receives the best assessment. Through a manual sampling, we found that almost 5 per cent of the opinions were not correctly classified. We consider this an acceptable value due to the complexity of natural language processing.

\section{Conclusions and future work}

A model was presented to transform CRM customer complaints, expressed in natural language, into SERVPERF scales. Several authors have adapted the SERVPERF to analyse satisfaction and dissatisfaction, but none have adopted a model to obtain this standard from unstructured CRM information. The proposed model is supported by:

- The idea of sentiment unit adapted to identify the SERVPERF features and their corresponding sentiments. This allows us to treat a complaint not as a unit but as different subunits corresponding to the SERVPERF scales on which the customer complains.

- The concept of fuzzy linguistic variable to represent these sentiments, as such fuzzy models are very appropriate to represent the uncertainty associated with these linguistic sentiments. 
- The 2-tuple model in order to compute (negation and aggregation operators) these sentiments without losing information.

- The proposed model, therefore, provides an accurate standard measure of the complaints, enabling better strategic management of these complaints on several fundamental aspects:

- We use internal information about the complaints contained in the CRM, providing advantages over possible SERVPERF ad-hoc studies based on surveys conducted by the company to obtain customer dissatisfaction information:

- Customers who complain frequently are reluctant to answer questionnaires.

- We could obtain several precise SERVPERF sub-surveys by grouping by any dimension, related to the customer, available in the CRM: customer segment, age, geographic location, etc.

- These surveys could be updated quasi in real time because the original information is collected by the support functions included in the CRM system.

- We could obtain enhanced over conventional Key Performance Indicators (KPIs) from the CRM customer complaints: rates of customer complaints, customer complaint average, number of complaints per month, etc. The following aspects are improved:

- These conventional KPIs could be segregated by the different SERVPERF scales.

- The calculation of KPIs could be more accurate because it takes into account the linguistic intensity of the complaint.

- We obtain customer level SERVPERF results allowing a better individual complaints management, improving loyalty programs and integrated communication with customers.

To prove the efficiency of the model and experimentally validate it, a prototype has been implemented and applied to a case study in a particular CRM system of Clearwire, a 4G multinational telecommunication company. The application of the prototype and its results has been described step by step. As a practical conclusion, most complaints are related to the technical aspects of services (tangibles, reliability and assurance) more than to staff (responsiveness and empathy). However, scales related to staff, responsiveness and empathy, are the worst valued by customers, whereas reliability receives a better assessment. As a point of improvement in the prototype, we note the identification of the particular business service portfolio as a feature on which customers could focus their complaints.

Regarding a weak point of our proposal, we could highlight the limitations of the 2-tuple linguistic model itself. This is based on a set of linguistic labels uniformly distributed in the context interval, which is why it does not conform to problems requiring an unbalanced solution space. As future work, we consider the possible scope for incorporating into our model other alternative fuzzy linguistic approaches as multi-granular or unbalanced fuzzy linguistic modelling.

The proposal was specially designed for its implementation in the telecommunications sector. However, we consider the possibility of experimentally applying this model to other economic areas where the process of making SERVPERF scale evaluations of the CRM customer complaints could be interesting. 


\section{Acknowledgements}

This paper has been developed with the financing of FEDER funds in the National Project TIN2016-75850-R.

\section{References}

Cabrerizo, F. J., Herrera-Viedma, E., \& Pedrycz, W. (2013). A method based on PSO and granular computing of linguistic information to solve group decision making problems defined in heterogeneous contexts. European Journal of Operational Research, 230(3), 624-633.

https://doi.org/10.1016/j.ejor.2013.04.046

Carrasco, R. A., Sánchez-Fernández, J., Muñoz-Leiva, F., Blasco, M. F., \& Herrera-Viedma, E. (2017). Evaluation of the hotels e-services quality under the user's experience. Soft Computing, 4(21), 9951011. https://doi.org/10.1007/s00500-015-1832-0

Chang, S. C., \& Tsai, P. H. (2016). A hybrid financial performance evaluation model for wealth management banks following the global financial crisis. Technological and Economic Development of Economy, 22(1), 21-46. https://doi.org/10.3846/20294913.2014.986771

Cid-López, A., Hornos, M. J., Carrasco, R. A., \& Herrera-Viedma, E. (2015). A hybrid model for decision-making in the information and communications technology sector. Technological and Economic Development of Economy, 21(5), 720-737. https://doi.org/10.3846/20294913.2015.1056281

Cronin Jr, J. J., \& Taylor, S. A. (1994). SERVPERF versus SERVQUAL: reconciling performance-based and perceptions-minus-expectations measurement of service quality. Journal of Marketing, 58(1), 125-131. https://doi.org/10.2307/1252256

De Maio, C., Fenza, G., Loia, V., \& Orciuoli, F. (2016a). Linguistic fuzzy consensus model for collaborative development of fuzzy cognitive maps: a case study in software development risks. Fuzzy Optimization and Decision Making, 1-17.

De Maio, C., Tommasetti, A., Troisi, O., Vesci, M., Fenza, G., \& Loia, V. (2016b). Contextual fuzzybased decision support system through opinion analysis: a case study at university of the Salerno. International Journal of Information Technology \& Decision Making, 15(05), 923-948. https://doi.org/10.1142/S0219622016500231

Elkhalifa, L., Adaikkalavan, R., \& Chakravarthy, S. (2005, March). InfoFilter: a system for expressive pattern specification and detection over text streams. ACM Symposium on Applied Computing. Santa Fe, New Mexico, USA. https://doi.org/10.1145/1066677.1066923

Ferreira, F. A., Ferreira, J. J., Fernandes, C. I., Meidutė-Kavaliauskienė, I., \& Jalali, M. S. (2017). Enhancing knowledge and strategic planning of bank customer loyalty using fuzzy cognitive maps. Technological and Economic Development of Economy, 23(6), 1-17.

https://doi.org/10.3846/20294913.2016.1213200

Gambetta, N., Zorio-Grima, A., \& García-Benau, M. A. (2015). Complaints management and bank risk profile. Journal of Business Research, 68(7), 1599-1601. https://doi.org/10.1016/j.jbusres.2015.02.002

Hadden, J., Tiwari, A., Roy, R., \& Ruta, D. (2006, May). Churn prediction using complaints data. Conference World Academy of Science, Engineering and Technology, 13, 158-163.

Hadidi, L., Assaf, S., \& Alkhiami, A. (2017). A systematic approach for ERP implementation in the construction industry. Journal of Civil Engineering and Management, 23(5), 594-603. https://doi.org/10.3846/13923730.2016.1215348

Hajek, P., Olej, V., \& Myskova, R. (2014). Forecasting corporate financial performance using sentiment in annual reports for stakeholders' decision-making. Technological and Economic Development of Economy, 20(4), 721-738. https://doi.org/10.3846/20294913.2014.979456 
Herrera, F., \& Martínez, L. (2000). A 2-tuple fuzzy linguistic representation model for computing with words. IEEE Transactions on Fuzzy Systems, 8(6), 746-752. https://doi.org/10.1109/91.890332

Hiroshi, K., Tetsuya, N., \& Hideo, W. (2004, August). Deeper sentiment analysis using machine translation technology. 20th International Conference on Computational Linguistics. Geneva, Switzerland. https://doi.org/10.3115/1220355.1220426

Jain, P. (2013). Telecommunication service quality assessment: a comparative study of Bharat Sanchar Nigam Limited and Reliance Communications Limited. Asia-Pacific Journal of Management Research and Innovation, 9(1), 99-106. https://doi.org/10.1177/2319510X13483517

Jain, P., Tomar, A., \& Vishwakarma, N. (2016). Analysis of customer satisfaction in Telecom Sector on implementation of CRM with respect to users. International Journal of Engineering, Management \& Medical Research, 2(3), 1-8.

Jain, S. K., \& Gupta, G. (2004). Measuring service quality: SERVQUAL vs. SERVPERF scales. Vikalpa, 29(2), 25-37. https://doi.org/10.1177/0256090920040203

Jain, T. I., \& Nemade, D. (2010). Recognizing contextual polarity in phrase-level sentiment analysis. International Journal of Computer Applications, 7(5), 5-11. https://doi.org/10.5120/1160-1453

Kim, S. M., \& Hovy, E. (2004, August). Determining the sentiment of opinions. 20th International Conference on Computational Linguistics. Geneva, Switzerland. https://doi.org/10.3115/1220355.1220555

Lai, F., Griffin, M., \& Babin, B. J. (2009). How quality, value, image, and satisfaction create loyalty at a Chinese telecom. Journal of Business Research, 62(10), 980-986. https://doi.org/10.1016/j.jbusres.2008.10.015

Lee, C. H., Wang, Y. H., \& Trappey, A. J. (2015). Ontology-based reasoning for the intelligent handling of customer complaints. Computers \& Industrial Engineering, 84, 144-155. https://doi.org/10.1016/j.cie.2014.11.019

Li, Y., \& Liu, P. (2015). Some Heronian mean operators with 2-tuple linguistic information and their application to multiple attribute group decision making. Technological and Economic Development of Economy, 21(5), 797-814. https://doi.org/10.3846/20294913.2015.1055614

Martínez-Cruz, C., Porcel, C., Bernabé-Moreno, J., \& Herrera-Viedma, E. (2015). A model to represent users trust in recommender systems using ontologies and fuzzy linguistic modeling. Information Sciences, 311, 102-118. https://doi.org/10.1016/j.ins.2015.03.013

Maurer, C., \& Schaich, S. (2011). Online customer reviews used as complaint management tool. In R. Law, M. Fuchs \& F. Ricci (Eds.), Information and communication technologies in tourism. New York, NY: Springer-Wien. https://doi.org/10.1007/978-3-7091-0503-0_40

Mi, C., Shan, X., Qiang, Y., Stephanie, Y., \& Chen, Y. (2014). A new method for evaluating tour online review based on grey 2-tuple linguistic. Kybernetes, 43(3/4), 601-613. https://doi.org/10.1108/K-06-2013-0123

Morente-Molinera, J. A., Mezei, J., Carlsson, C., \& Herrera-Viedma, E. (2017). Improving supervised learning classification methods using multi-granular linguistic modelling and fuzzy entropy. IEEE Transactions on Fuzzy Systems, 25(5), 1078-1089. https://doi.org/10.1109/TFUZZ.2016.2594275

Naik, C. K., Gantasala, S. B., \& Prabhakar, G. V. (2010). Service quality (SERVQUAL) and its effect on customer satisfaction in retailing. European Journal of Social Sciences, 16(2), 231-243.

Nakov, P., Kozareva, Z., Ritter, A., Rosenthal, S., Stoyanov, V., \& Wilson, T. (2013, June). Sentiment analysis in Twitter. 7th International Workshop on Semantic Evaluation. Atlanta, Georgia, USA.

Pang, B., \& Lee, L. (2004, July). A sentimental education: sentiment analysis using subjectivity summarization based on minimum cuts. 42nd Annual Meeting on Association for Computational Linguistics. Barcelona, Spain. https://doi.org/10.3115/1218955.1218990

Parasuraman, A., Zeithaml, V. A., \& Berry, L. L. (1985). A conceptual model of service quality and its implications for future research. Journal of Marketing, 49, 41-50. https://doi.org/10.2307/1251430 
Picón, A., Castro, I., \& Roldán, J. L. (2014). The relationship between satisfaction and loyalty: a mediator analysis. Journal of Business Research, 67(5), 746-751. https://doi.org/10.1016/j.jbusres.2013.11.038

Piepiorra, F. (2015). vtiger CRM v6. 2.0-User and Administration Manual. Lulu.

Prabowo, R., \& Thelwall, M. (2009). Sentiment analysis: a combined approach. Journal of Informetrics, 3(2), 143-157. https://doi.org/10.1016/j.joi.2009.01.003

Shea, C., Faisal, M., Ford, R., Lin, W., \& Matsuda, Y. (2008). Oracle Text Reference 11g. Release 1: Oracle Corporation.

Shen, J., Tang, S., \& Zhu, H. (2010, August). The investigation in service quality management of 3G business for telecom operators. International Conference on Management and Service Science. Wuhan, China. https://doi.org/10.1109/ICMSS.2010.5577082

Snyder, M., Steger, J., \& Landers, B. (2011). Microsoft Dynamics CRM 2011 step by step. Pearson Education.

Tax, S. S., Brown, S. W., \& Chandrashekaran, M. (1998). Customer evaluations of service complaint experiences: Implications for relationship marketing. Journal of Marketing, 62, 60-76. https://doi.org/10.2307/1252161

Trainor, K. J., Andzulis, J. M., Rapp, A., \& Agnihotri, R. (2014). Social media technology usage and customer relationship performance: a capabilities-based examination of social CRM. Journal of Business Research, 67(6), 1201-1208. https://doi.org/10.1016/j.jbusres.2013.05.002

Van der Wal, R. W. E., Pampallis, A., \& Bond, C. (2002). Service quality in a cellular telecommunications company: a South African experience. Managing Service Quality: An International Journal, 12(5), 323-335. https://doi.org/10.1108/09604520210442119

Wisniewski, M. (2001). Using SERVQUAL to assess customer satisfaction with public sector services. Managing Service Quality: An International Journal, 11(6), 380-388. https://doi.org/10.1108/EUM0000000006279

Yilmaz, C., Varnali, K., \& Kasnakoglu, B. T. (2016). How do firms benefit from customer complaints?. Journal of Business Research, 69(2), 944-955. https://doi.org/10.1016/j.jbusres.2015.08.038

Zadeh, L. A. (1975). The concept of a linguistic variable and its applications to approximate reasoning, Pt I. Information Sciences, 8, 199-249. Pt II, Information Sciences, 8, 301-357. Pt III, Information Sciences, 9, 43-80. https://doi.org/10.1016/0020-0255(75)90046-8 